\title{
Trade Potential of China's Export to ASEAN: The Gravity Model Using New Economic Mass Proxies
}

\author{
Yuqin ZHANG ${ }^{\dagger}$ \\ School of Public Administration, University of International Business and Economics, Beijing 100029, \\ China \\ E-mail: yqzhang@uibe.edu.cn \\ Shouyang WANG \\ Academy of Mathematics and Systems Science, Chinese Academy of Sciences, Beijing 100190, China \\ E-mail: sywang@amss.ac.cn
}

\begin{abstract}
Considering the fact that China is the world factory, in which the trade of intermediate goods has a relatively high share and especially that the trade of intermediate goods with ASEAN is even higher, it is not suitable to use GDP as the economic mass proxies in the gravity model to estimate trade flows traditionally. This paper, by using the data between China and 10 member states of ASEAN along with other 12 main trading partners of China from 1999 to 2013, constructs China's bilateral export equation based on the gravity model using new economic mass proxies according to Baldwin and Taglioni, and then calculates the trade potential index of China's export to the member states of ASEAN by using this equation. The empirical results show that, China's export trade equation based on new economic mass proxy has stronger explanatory power compared to the standard gravity model by using GDP as economic mass proxy. Therefore, the calculating results of trade potential of China's export to ASEAN are more convincing.
\end{abstract}

Keywords gravity model; trade potential; trade intermediate goods; China-ASEAN free trade area

\section{Introduction}

China-ASEAN free trade area (CAFTA) was formally set up in 2010 since the first endeavor on it in 2002. Starting from the new century, the compound annual growth rate of China's export trade to ASEAN is $21.73 \%$ by the end of 2014, which is higher than that of China's total export trade of $17.36 \%$ during the same period ${ }^{1}$. Since the 2008 global financial crisis, in order to protect domestic industries, governments of different countries implemented nontariff barriers like green barriers and technical barriers, which greatly influenced China's export trade negatively. Under such a background, the Chinese government proposed the vision of building the update version of CAFTA in October 2013. In the situation that the growth of

Received August 9, 2015, accepted September 24, 2015

Yuqin Zhang acknowledges gratefully the financial support from the research project of the University of International Business and Economics (Trade Facilitation Index and Its Applications, No. TS3-04).

$\dagger$ The corresponding author

${ }^{1}$ The compound annual growth rates of China's export trade are calculated by the authors using the data from UN COMTRADE database. 
China's export trade is slowing down, CAFTA, as the biggest economic area of developing countries' trade cooperation, proactively promotes China's trade with ASEAN. To see if this can be an effective way for China to promote its export, we need to fully understand China's trade potential to ASEAN and whether there exists room for further improvement. This paper aims to answer this question through constructing China's bilateral export trade equation.

With the gradual implementation of the plan of CAFTA, lots of scholars have done researches on the topic of trade effects and trade potentials between China and ASEAN from the overall level ${ }^{[1-5]}$, industrial or product level ${ }^{[6-9]}$ and regional level ${ }^{[10-13]}$. These studies show that the establishment of CAFTA has promoted the bilateral trade between China and ASEAN, but there exist huge differences of trade potential of China with different ASEAN countries. The relevant papers also research on the static trade effects of CAFTA, of which most show that CAFTA has very strong trade creation effect while the trade diversion effect is weak. The empirical result by Chen and $\mathrm{Tu}^{[2]}$ is different, which states, by using the panel data analysis between 2000 to 2004, CAFTA has a stronger trade diversion effect compared to trade creation effect, and the reason is that there is relatively smaller trade volume between China and the member states of ASEAN than that between China and Non-ASEAN countries.

In the literatures analyzing bilateral trade flows between China and ASEAN based on gravity model, they generally use GDP as the economic mass proxies. Since the theoretic foundation of gravity model is based on consumption theory, so it is suitable for traditional ways of trade. However, as the world factory, China has a relative larger scale trade of intermediate goods ${ }^{2}$ as inputs, which doesn't rely on added value, but on total value of output. For the bilateral trade between China and ASEAN, the share of intermediate goods is even higher. In 2013, the trade of intermediate goods accounts for $64.31 \%$ of the total trade for china export to ASEAN, obviously higher than that $51.21 \%$ of total export of $\mathrm{China}^{3}$. So if we still use the value added index of GDP as the economic mass proxy in such a situation, then it might lead to inaccurate research result. For this reason, this paper, according to Baldwin and Taglioni ${ }^{[14]}$, uses new economic mass proxies based on industrial added value and intermediate import goods as proxies of GDP to construct China's export trade equation, and also does analysis by using GDP as the economic mass proxy, and then compares both of the analysis results. The result shows that the export trade equation constructed by using the new economic mass proxies can better explain China's bilateral export.

According to the existing data composition of trade flows by using gravity model, there are mainly two kinds: Cross-section data and panel data. And from the perspective of the number of studying subjects, there are single-country model and multi-country model. The single-country model refers to international trade between a country (region) and other countries as studying subject, while multi-country model refers to research on bilateral trade among all the studying subjects. This paper, by using single-country gravity model, analyzes China's export trade to the member states of ASEAN along with its other main trading partners, and then constructs China's export trade equation to calculate China's export potential to ASEAN countries.

\footnotetext{
${ }^{2}$ According to UN's Classification by Broad Economic Categories, intermediate goods include goods of No.111, No.121, No.21, No.22, No.32, No.42 and No.53 from UN COMTRADE database.

${ }^{3}$ The shares of intermediate goods of China's export trade are calculated by the authors using the data from UN COMTRADE database.
} 
The rest of this paper is organized as follows. Section 2 presents the augmented gravity model of using the new economic mass proxies. Section 3 is data and the empirical results. In Section 4, trade potential index of China's export to ASEAN countries is calculated based on China's export trade equation in Section 3. Section 5 concludes the paper.

\section{The Augmented Gravity Model Using the New Economic Mass Proxies}

For studying China's export potential to ASEAN, this paper constructs the export trade equation on the basis of the augmented gravity model using new economic mass proxies according to Baldwin and Taglioni ${ }^{[14]}$. In order to compare the effects on dependent variables of different economic mass proxies, this paper constructs the following two equations:

$$
\begin{aligned}
& \ln \left(E X_{c f t}\right)=\alpha_{0}+\alpha_{1} \ln \left(\frac{Y_{c t}}{\Omega_{c t}} \cdot \frac{Y_{f t}}{P_{f t}^{1-\sigma}}\right)+\alpha_{2} \ln \left(\tau_{c f t}\right)+\epsilon_{c f t} \\
& \ln \left(E X_{c f t}\right)=\beta_{0}+\beta_{1} \ln \left(\frac{C_{c t}}{\Omega_{c t}} \cdot \frac{E_{f t}}{P_{f t}^{1-\sigma}}\right)+\beta_{2} \ln \left(\tau_{c f t}\right)+\epsilon_{c f t}
\end{aligned}
$$

where

$$
\begin{aligned}
& \Omega_{c t}=\left(\Sigma_{f} \operatorname{GDP}_{f t} *\left(\operatorname{Dist}_{c f}\right)^{1-\sigma}\right)^{\frac{1}{1-\sigma}} \\
& C_{c} \equiv A V_{c t}^{\text {manuf }}+\Sigma_{i \neq c} E X_{i f t}^{\text {interm }} \\
& E_{f t} \equiv Y_{f t}+\Sigma_{i \neq c} E X_{f i t}^{\text {interm }}
\end{aligned}
$$

The subscripts $c, f$ and $t$ stand for the China, the trade partner of China and the time period, respectively. The definitions of the variables from formulas (1) to (5) are as follows:

$E X_{c f}$ is China's bilateral export value to its trading partner.

$Y_{c}$ and $Y_{f}$ are the nominal GDP of China and the nominal GDP of China's trading partner respectively.

$\Omega_{c}$ and $P_{f}$ represent market potential index and price index respectively, which are unobservable and yet includes factors that enter the regressions independently. Thus ignoring them can lead to serious biases ${ }^{[14]}$. For estimating $\Omega_{c}$, assuming $\sigma=4$ in formulas $(1) \sim(3)$ according to Obstfeld and Rogoff ${ }^{[15]}$ and Carrère ${ }^{[16]}$. In the actual operations of formulas (1) and (2), the economic mass proxy of China's trading partner is expressed by its actual value as to account for $P_{f}$ implicitly.

$\tau_{c f}$ are the trade cost factors between China and its trading partner, including factors like logarithm of bilateral distance between China and its trading partner $(\ln ($ Dist $)$ ), and dummy variables indicating whether the trading partner is contiguous to China (contig), shares a common language with China (comlang), and is a member of CAFTA (FTA). Furthermore, the nominal effective exchange rate of RMB as the price factor influencing on China's bilateral export is also considered, of which the details can be seen in Table 1.

$C_{c t}$ is the new economic mass proxy replacing China's nominal GDP. It comprises of two parts, of which $A V_{c}^{\text {manuf }}$ represents the added value of China's manufacturing industry and $\Sigma_{i \neq c} E X_{i f}^{\text {interm }}$ represents its purchases of intermediate inputs from all sources except from itself (due to a lack of data). 
$E_{f t}$ represents the new economic mass proxy replacing nominal GDP of China's trading partner. It also comprises of two parts, of which $Y_{f}$ is nominal GDP of China's trading partner and $\Sigma_{i \neq c} E X_{f i}^{\text {interm }}$ which is total bilateral export value of intermediate goods of China's trading partner.

Table 1 Gravity variables illustrations, data sources and symbol expectation of regression coefficients

\begin{tabular}{|c|c|c|c|}
\hline Variables & Definition & Data Sources & Symbol Expectation \\
\hline $\ln \left(E X_{c f}\right)$ & $\begin{array}{l}\text { Logarithm of bilateral export } \\
\text { value of China to its trading } \\
\text { partners }\end{array}$ & UN COMTRADE & -- \\
\hline$M_{f}^{\text {interm }} / M_{f}$ & $\begin{array}{l}\text { The share of trading partners } \\
\text { import from China on its total } \\
\text { import }\end{array}$ & UN COMTRADE & + \\
\hline $\ln \left(Y_{c} Y_{f} / \Omega_{c} P_{f}\right)$ & $\begin{array}{l}\text { Logarithm of China and its } \\
\text { trading partners' nominal } \\
\text { GDP considering multilateral } \\
\text { trade resistance }\end{array}$ & World Bank & + \\
\hline $\ln \left(C_{c} E_{f} / \Omega_{c} P_{f}\right)$ & $\begin{array}{l}\text { Logarithm of China and its } \\
\text { trading partners' new eco- } \\
\text { nomic mass proxies considering } \\
\text { multilateral trade resistance }\end{array}$ & World Bank & + \\
\hline $\ln ($ Dist $)$ & $\begin{array}{l}\text { Logarithm of the bilateral dis- } \\
\text { tance between China and its } \\
\text { trading partners }\end{array}$ & CEPII & - \\
\hline Contig & $\begin{array}{l}\text { Dummy variable indicating } \\
\text { whether the trading partner is } \\
\text { contiguous to China }\end{array}$ & CEPII & + \\
\hline Comlang & $\begin{array}{l}\text { Dummy variable indicating } \\
\text { whether the trading partner } \\
\text { shares common language with } \\
\text { china }\end{array}$ & CEPII & + \\
\hline FTA & $\begin{array}{l}\text { Dummy variable indicating } \\
\text { whether the trading partner is } \\
\text { the member states of ASEAN }\end{array}$ & ASEAN Secretariat & + \\
\hline $\ln (n r m b)$ & $\begin{array}{l}\text { Logarithm of RMB nominal ef- } \\
\text { fective exchange rate }\end{array}$ & IMF & $?-$ \\
\hline
\end{tabular}

Table 1 provides the expected symbols of independent variables' regression coefficient in China's export trade equation. Based on the standard gravity model, the regression coefficient of bilateral distance is expected to be negative, while the regression coefficients of other influencing factors of economic mass proxies, contiguity, common official languages and membership of CAFTA are expected to be positive. Besides, detailed explanations of other variables are as follows: According to Baldwin and Taglioni ${ }^{[14]}$, the higher the ratio of intermediate goods 
imports in total imports, the more of bilateral export would be, compared to the expectation of standard gravity model, which means the regression coefficients of $M_{f}^{\text {interm }} / M_{f}$ is expected to be positive. Under the way of traditional trade, the international competitiveness of China's exports would decrease with increasing of the nominal effective exchange rate of RMB, thus the regression coefficient of $\ln (n r m b)$ is expected to be negative. However, China as the world factory, of which the processing trade and intermediate goods trade have a relatively large share, the nominal effective exchange rate of RMB might not have a statistically significant influence on China's export trade. Therefore, the expected symbols of regression coefficient of $\ln (\mathrm{nrmb})$ are assumed to be indefinite ('?-' is used to express the implication in Table 1).

\section{Data and Empirical Results}

\subsection{Data and Its Sources}

According to the historical data of China's international trade flow, the trading partners selected by this paper are the same with that of Chen and $\mathrm{Tu}^{[2] 4}$. This paper estimates China's export equation based on the panel data between China and 10 ASEAN countries along with its other 12 main trading partners ${ }^{5}$ from 1999 to 2013, including Brunei Darussalam (BRN), Myanmar (MMR), Cambodia (KHM), Indonesia (IDN), Lao PDR (LAO), Malaysia (MYS), Philippines (PHL), Singapore (SGP), Thailand (THA), Vietnam (VNM), Hong Kong SAR of China (HKG), Japan (JPN), Republic of Korea (KOR), United Kingdom (GBR), Germany (DEU), France (FRA), Italy (ITA), Netherlands (NLD), Russian Federation (RUS), Canada (CAN), United States (USA) and Australia (AUS). Since the gradual implementation of the plan of CAFTA started on 2002, this paper sets the year of 2002 as the turning point to forecast the trade effect of CAFTA. In this regard, the value of dummy variable of FTA for ASEAN member states is assumed as 0 before 2002, and as 1 in and after 2002, while always as 0 for other trading partners of China.

Table 1 provides the data sources used in this paper. The data used for the bilateral trade flows is taken from UN COMTRADE database. GDPs are from the World Development Indicators of the World Bank. Data of bilateral distance, contiguity and common language, are from CEPII database. The nominal effective exchange rate of RMB is from IMF.

\subsection{Empirical Results}

Table 2 presents China's export trade equation based on gravity model. 4 equations are included in this table. Models (1) and (2) are China's bilateral export trade equations built on the gravity model of using GDPs of both trading partners as economic mass proxies. Models (3) and (4) are China's bilateral export trade equations constructed on the gravity model of using new economic mass proxies according to Baldwin and Taglioni ${ }^{[14]}$. Models (1) and (3) are the standard gravity models only including 2 key variables mainly influencing trade flows, i.e., economic mass proxies and bilateral distance. Models (2) and (4), on the basis of Models (1)

\footnotetext{
${ }^{4}$ Compared to the equation estimated in their work, this paper takes the multilateral trade resistance into account and considers more factors influencing China's bilateral export, which would greatly decrease the potential threat of omitting variable bias when the regression equation is constructed.

${ }^{5}$ Because of the unavailability of the data of Taiwan, though as the main trading partner of mainland China, Taiwan cannot be included in this paper.
} 
and (3), have added factors like the dummy variables indicating whether the trading partner is contiguous to China, shares common official language with China, and is a member countries of CAFTA. The nominal effective exchange rate of RMB is also taken into account. Besides, the important factor of the share of import of intermediate goods on total import of trading partners, and then its mutual effect with other variables are included.

Table 2 China's export trade equation based on gravity model (1999-2013) ${ }^{6}$

\begin{tabular}{|c|c|c|c|c|}
\hline Variables & (1) & $(2)$ & $(3)$ & (4) \\
\hline$M_{f}^{\text {interm }} / M_{f}$ & & $\begin{array}{l}20.7188^{* * *} \\
(2.3227)\end{array}$ & & $\begin{array}{l}19.6283^{* * *} \\
(2.1729)\end{array}$ \\
\hline $\ln \left(Y_{c} Y_{f} / \Omega_{c} P_{f}\right)$ & $\begin{array}{l}0.8433^{* * *} \\
(0.0227)\end{array}$ & $\begin{array}{l}1.1064^{* * *} \\
(0.0275)\end{array}$ & & \\
\hline$* M_{f}^{\text {interm }} / M_{f}$ & & $\begin{array}{l}-0.3429^{* * *} \\
(0.0407)\end{array}$ & & \\
\hline $\ln \left(C_{c} E_{f} / \Omega_{c} P_{f}\right)$ & & & $\begin{array}{l}0.8578^{* * *} \\
(0.0197)\end{array}$ & $\begin{array}{l}1.0748^{* * *} \\
(0.0254)\end{array}$ \\
\hline$* M_{f}^{\text {interm }} / M_{f}$ & & & & $\begin{array}{l}-0.3288^{* * *} \\
(0.0383)\end{array}$ \\
\hline $\ln$ (Dist) & $\begin{array}{l}-0.9491^{* * *} \\
(0.0866)\end{array}$ & $\begin{array}{l}-0.5823^{* * *} \\
(0.057)\end{array}$ & $\begin{array}{l}-0.9113^{* * *} \\
(0.0752)\end{array}$ & $\begin{array}{l}-0.5837^{* * *} \\
(0.0539)\end{array}$ \\
\hline Contig & & $\begin{array}{l}2.1688^{* * *} \\
(0.2165)\end{array}$ & & $\begin{array}{l}1.7947^{* * * *} \\
(0.2049)\end{array}$ \\
\hline$* M_{f}^{\text {interm }} / M_{f}$ & & $\begin{array}{l}-2.5732^{* * *} \\
0.3075\end{array}$ & & $\begin{array}{l}-2.0143^{* * *} \\
(0.2918)\end{array}$ \\
\hline Comlang & & $\begin{array}{l}5.4718^{* * *} \\
(0.6555)\end{array}$ & & $\begin{array}{l}4.2401^{* * *} \\
(0.6206)\end{array}$ \\
\hline$* M_{f}^{\text {interm }} / M_{f}$ & & $\begin{array}{l}-5.1454^{* * *} \\
(0.8494)\end{array}$ & & $\begin{array}{l}-3.9226^{* * *} \\
(0.8036)\end{array}$ \\
\hline FTA & & $\begin{array}{l}0.4267 * * * \\
(0.0714)\end{array}$ & & $\begin{array}{l}0.2415^{* * *} \\
(0.0651)\end{array}$ \\
\hline $\ln (n r m b)$ & & $\begin{array}{l}-1.0894^{* *} \\
(0.4315)\end{array}$ & & \\
\hline Constant & $\begin{array}{l}-17.6592^{* * *} \\
(1.2062)\end{array}$ & $\begin{array}{l}-32.037^{* * *} \\
(2.2859)\end{array}$ & $\begin{array}{l}-18.5706^{* * *} \\
(1.0557)\end{array}$ & $\begin{array}{l}-34.6543^{* * *} \\
(1.4036)\end{array}$ \\
\hline Observations & 330 & 330 & 330 & 330 \\
\hline Adjusted R-squared & 0.8094 & 0.9383 & 0.8534 & 0.9446 \\
\hline
\end{tabular}

Data source: Calculated according to the original data by the authors. Note: The value in the bracket is the standard deviations of the regression coefficient of export equation. The superscript *** means $P<0.01$, and ** means $P<0.05$.

By comparing models (1) and (3), models (2) and (4) respectively, it is found out that the export equations using the new economic mass proxies have better goodness of fit. The adjusted $\mathrm{R}$ squared values of the models (2) and (4) using new economic mass are always higher than that of the ones using GDPs as the economic mass proxies. It demonstrates that when the trade of intermediate goods has a big share using the new economic mass proxies is more appropriate than using GDP as economic mass proxies. Furthermore, it shows that RMB nominal effective exchange rate has a statistically significant negative influence on China's bilateral export trade

\footnotetext{
${ }^{6}$ The results from this table are obtained based on the stepwise regression analysis by using Eviews 8.0, and the variables are not included in the equation which regression coefficient is not statistically significant.
} 
value in model (2), but this factor is not included in model (4). This is because that RMB nominal effective exchange rate does not have a statistically significant influence on China's bilateral export trade value in the regression equation of using the new economic mass proxies. When the trade of intermediate goods has a big share, the influence of RMB nominal effective exchange rate on export trade is neutral. The reason is that the appreciation of exchange rate is favorable to import trade instead of export trade, so the influence becomes neutral to the import of processing trade, which is used for processing export. And this can also exactly reflect that China's bilateral export trade equation constructed based on the gravity model of using the new economic mass proxies is more appropriate.

This paper selects model (4) in Table 2 as the equation estimating China's bilateral export trade based on the analysis above. All the regression coefficients of different variables in model (4) are also in line with what expected. The share of intermediate goods import on total import of trading partners is an important factor, and the mutual effects of some of other variables with it, like the new economic mass proxies, contiguity and common official languages, are statistically significant. And the symbols of regression coefficients are all negative, which means these mutual effects decrease the influence of different variables to China's bilateral export value compared to the estimation based on standard gravity model. However, the mutual effect of other variables with it, like bilateral distance, the dummy variable indicating whether it is a member of CAFTA and the nominal exchange rate of RMB is not statistically significant. The results are different from that of Baldwin and Taglioni ${ }^{[14]}$, which shows that the mutual effect between the share of intermediate goods import on total import of trading partners and distance is statistically significant. This is because, in terms of studying subjects, Baldwin and Taglioni ${ }^{[14]}$ selects a broader range of studying subjects, while this paper selects China and ASEAN countries along with other main trading partners of China as studying subjects. Based on the historical data of trade in intermediate goods, it is more outstanding in China, as the world factory, so the results based on China are more convincing.

Comparing models (3) and (4), both distance and the new economic mass proxies are statistically significant and the symbols of regression coefficient are in line with what expected. The import share coefficient of intermediate goods of trading partners in model (4) is positive, which means, compared to the expectation of standard gravity model, this would have more trade with trading partners with a higher proportion of intermediate goods in bilateral trade. Moreover, compared to model (3), the coefficient of the new economic mass proxies in model (4) becomes bigger, while the regression coefficient of bilateral distance becomes smaller significantly. This means that when consider the factor of intermediate goods import share of trading partners, the economy mass proxy is more important, but the factor of bilateral distance becomes less important. why would this happen? We will study this problem in the future work.

\section{Trade Potentials of China's Export to ASEAN Countries}

Trade potential index of China's export to ASEAN countries is calculated based on the equation of China's bilateral export trade constructed in Section 3. Firstly estimating China's bilateral export value to ASEAN countries based on the export trade equation, and taking it as the theoretic value in natural situation and then dividing the actual observed value of China's 
export to ASEAN by this theoretic value, the result is the trade potential value of China's export trade to ASEAN countries. According to the classification of trade potentials by Liu and Jiang ${ }^{[5]}$, if trade potential value is smaller than 0.8 , then the trading partner belongs to the type of huge potential, which means that there is a relatively big room for further improvement of China's export to this partner. If trade potential value is between 0.8 and 1.2 , then the trading partner belongs to the type of potential to be further explored, which means that the China's export potential to this country has not been fully developed and it needs to be further explored. If trade potential value is bigger than 1.2, then the trading partner belongs to the type of potential to be recreated, which means that China's export potential to this partner has been fully developed, and new influencing factors need to be developed and cultivated if China's export trade to this partner is further promoted.

Table 3 Trade potential index of China's export to ASEAN countries (1999-2013)

\begin{tabular}{ccccccccccc}
\hline & \multicolumn{1}{c}{ Country } \\
\cline { 2 - 10 } Year & BRN & IDN & KHM & LAO & MMR & MYS & PHL & SGP & THA & VNM \\
\hline 1999 & 2.49 & 0.88 & 1.07 & 2.98 & 0.80 & 1.85 & 0.84 & 0.94 & 1.17 & 0.91 \\
2000 & 1.97 & 0.59 & 0.94 & 1.98 & 0.80 & 1.78 & 0.99 & 1.02 & 0.94 & 0.81 \\
2001 & 1.55 & 0.75 & 0.89 & 1.62 & 0.77 & 1.32 & 0.97 & 0.99 & 0.93 & 0.77 \\
2002 & 1.91 & 0.88 & 0.80 & 2.41 & 0.70 & 1.25 & 1.18 & 1.20 & 1.04 & 1.03 \\
2003 & 1.58 & 0.85 & 0.90 & 1.68 & 0.56 & 1.42 & 0.92 & 1.25 & 0.98 & 0.96 \\
2004 & 1.49 & 0.78 & 0.93 & 2.09 & 0.67 & 1.44 & 0.88 & 1.21 & 0.83 & 1.08 \\
2005 & 1.68 & 0.70 & 0.92 & 2.47 & 0.77 & 1.21 & 0.98 & 1.24 & 0.75 & 1.09 \\
2006 & 1.19 & 0.81 & 0.90 & 1.91 & 0.68 & 1.16 & 1.05 & 1.11 & 0.76 & 1.01 \\
2007 & 1.37 & 0.79 & 0.94 & 2.30 & 0.61 & 1.12 & 1.05 & 1.28 & 0.80 & 0.91 \\
2008 & 1.54 & 0.79 & 0.68 & 1.88 & 0.76 & 1.21 & 1.00 & 1.44 & 0.77 & 1.06 \\
2009 & 1.29 & 0.83 & 0.77 & 1.40 & 0.76 & 1.22 & 0.90 & 1.52 & 0.80 & 0.89 \\
2010 & 0.76 & 0.79 & 0.77 & 1.44 & 0.78 & 1.39 & 0.94 & 1.75 & 0.82 & 0.78 \\
2011 & 0.51 & 0.80 & 0.53 & 1.86 & 0.70 & 1.51 & 0.93 & 2.31 & 0.83 & 0.87 \\
2012 & 0.33 & 0.77 & 0.40 & 1.06 & 0.68 & 1.27 & 0.91 & 1.91 & 0.76 & 0.81 \\
2013 & 0.33 & 0.80 & 0.38 & 0.65 & 0.55 & 1.00 & 0.88 & 1.67 & 0.80 & 0.63 \\
\hline
\end{tabular}

According to the analysis above, this paper takes model (4) in Table 2 as the estimated equation of China's bilateral export trade and then calculates the trade potential of China's export trade to ASEAN countries from 1999 to 2013. The results in Table 3 show that there is big difference among China's export trade potential to ASEAN countries. Under the status quo, Brunei Darussalam, Lao PDR, Malaysia and Singapores export trade potential values have had reached 1.2, or even bigger than 2.0 in some years. This means that China's export potential to these countries at different years has been greatly developed. However, these 4 countries have also shown different characteristics. With the formal establishment of CAFTA in 2010, export potential indexes of Lao PDR, Malaysia and Singapore had all increased greatly at different years after 2010, but started to decrease since 2012, while the trade potential index of China's 
export to Brunei Darussalam hasn't increased with the establishment of CAFTA, but decreased continuously since 2009. Besides the above-mentioned 4 countries, the trade potential indexes of China's export to the rest 6 countries of ASEAN are all below 1.2.

Generally speaking, from 2011 to 2013, due to the slowdown of China's export trade, the trade potential index of China's export to ASEAN countries had all decreased. According to the information of trade potentials from 2011 to 2013 in Table 3, classification of the member states of ASEAN according to trade potentials with China is summarized as follows.

Firstly as to the type of huge potential, there is huge potential for China to further expand export trade to this type of trading partners. The reason causing this serious shortage of trade is the serious trade barrier existing between China and this type of countries. It resides on making out preferential regional trade mechanism arrangement to avoid trade barrier for further developing trade with these countries. Among 10 ASEAN countries, trade potential value of 2011-2013 of Brunei Darussalam, Indonesia, Cambodia and Myanmar are all less than 0.8. China's export trade potential to these 4 countries is huge, so we should find out China's competitive export products to these countries to proactively promote export trade according to comparative advantages.

Secondly as to the type of potential to be further explored, the trade potential of China's export to these countries has not been fully developed and there is further room of development. Philippines, Thailand and Viet Nam belong to this type among the 10 ASEAN countries.

Thirdly as to the type of potential to be recreated, the export potential of China to this type of trading partners has been developed. Therefore, in order to promote export trade to these countries, we need to maintain the existing positive factors and also proactively cultivate other factors to promote trade. Among the 10 ASEAN countries, Singapore, Malaysia and Lao PDR are of this type.

\section{Conclusions}

As to China, the world factory, the share of trade of intermediate goods on total trade value is above $50 \%$, and that of China's trade with ASEAN is even above $60 \%$, so the standard gravity model using GDP as economy mass proxy to estimate trade flows might not be appropriate under such a background. Therefore, this paper, according to Baldwin and Taglioni ${ }^{[14]}$, uses the data between China and 10 ASEAN countries along with other 12 main trading partners from 1999 to 2013, to construct the equation of China's bilateral export trade based on the gravity model by using the new economic mass proxies. The results show that the nominal effective exchange rate of RMB is not statistically significant in the export equation of using the new economic mass proxies, which exactly reflects the fact that processing trade and intermediate goods trade account for a big share in China's trade flows. Thus, the equation of China's bilateral export using the new economic mass proxies is more appropriate to estimate China's trade flows. The trade potential of China's export to ASEAN countries is calculated by applying the equation of China's bilateral export trade using the new economic mass proxies. It shows that the trade potential value of China's export to Singapore is very big, which indicates that the China's export potential to Singapore has been fully developed. China needs to find out new ways to promote export to Singapore in future. Beside it, with the slowdown of China's 
export growth in recent years, there is still a relatively huge room for China's export to ASEAN countries. Economic and trade cooperation with these countries should be proactively carried out based on China's comparative advantages to promote its export trade.

\section{References}

[1] Yanng S P, Martinez-Zarzoso I. A panel data analysis of trade creation and trade diversion effects: The case of ASEAN China Free Trade Area. China Economic Review, 2014, 29: 138-151.

[2] Chen H L, Tu Y. The static trade effects in China under CAFTA: An empirical analysis based on the gravity model. Journal of International Trade, 2007, 5: 47-50.

[3] Jiang S Z, Zhang X K. Gravity model of ASEAN trade effect. The Journal of Quantitative and Technical Economics, 2003, 10: 53-57.

[4] Jiang G, Huo Q. Trade creation effect and trade potential of CAFTA: Based on empirical analysis of the panel data of gravity model. Contemporary Economic Management, 2015, 2: 60-67.

[5] Liu Q F, Jiang S Z. Estimating China's bilateral trade arrangement based on trade gravity model. Zhejiang Social Sciences, 2002, 6: 17-20.

[6] Liang Y, Wang X R. Influencing factors and potential analysis of China's animal products exporting to ASEAN: Based on the empirical research of gravity model. Science and Management, 2011, 5: 42-46.

[7] Shao G L, Hu X. A study of trade flow and potential of Sina-ASEAN aquatic product trade based on a gravity model. Journal of Ocean University of China (Social Sciences), 2013, 5: 34-39.

[8] Xie S N, Yang J, Liu H G, et al. Agricultural trade structure change, competitiveness and complementarities between China and ASEAN countries. Journal of Hunan Agricultural University (Social Sciences), 2013, 2: $10-15$.

[9] Zhao Y L, Lin G H. Trade flows and potentials of bilateral agricultural products trade between China and 10 ASEAN countries: A study based on trade gravity model. Journal of International Trade, 2008, 12: 69-77.

[10] Li Q, Zhao G. Trade potential of Guizhou's export to ASEAN: Based on the trade gravity model. Enterprise Economy, 2014, 7: 143-147.

[11] Tan H Y. An empirical study on trade flow between Yunnan and ASEAN: Based on trade gravity model. Journal of Anhui Administration Institute, 2015, 1: 63-66.

[12] Xue W D, Shan Y. Influencing factors of trade effect between Yunnan and ASEAN countries: An empirical analysis based on trade gravity model. Journal of Yunnan University of Finance and Economics (Social Sciences), 2010, 2: 18-21.

[13] Zhuang L J, Jiang Y W, Liu N. Trade flows and potentials of agricultural products trade between Guangdong and ASEAN: A study based on gravity model. Journal of International Trade, 2007, 6: 81-86.

[14] Baldwin R E, Taglioni D. Gravity chains: Estimating bilateral trade flows when parts and components trade is important. Journal of Banking and Financial Economics, 2014, 2(2): 61-82.

[15] Obstfeld M, Rogoff K. The six major puzzles in international macroeconomics: Is there a common cause? NBER Working Paper 7777, 2002.

[16] Carrère C. Revisiting the effects of regional trade agreements on trade flows with proper specification of the gravity model. European Economic Review, 2006, 50(2): 223-247. 